schemes referred to in the report, and generally approved by competent persons, should be taken up by the Advisory Council on Atmospheric Pollution, who should bring it before the notice of the public in the form of active propaganda. It seems useless to make vearly records of air pollution when no serious steps are being taken, publicly or privately, to diminish the evil.

J. B. C.

\section{Work of the Analytical Laboratory, Cairo.}

SEVERAL features of more than passing interest $S$ are shown in the undermentioned report. ${ }^{1}$ Covering as it does the period of the war, it chronicles work-such as the making of special incendiary bombs and chemical igniters for flareswhich is rather unusual for the analytical laboratory, but is an indication of versatility in time of need. Passing, however, to more normal activities, with a bare mention of the excellent routine work done, it is interesting to note that research has taken a definite place in the programme of the department; the authorities are evidently alive to the importance of encouraging the application of chemistry to arts and manufactures. Thus an investigation of Egyptian crude petroleum has been made, the results of which have proved that good yields of Diesel fuel-oil can be obtained from this source, besides the customary petroleum spirit and kerosene, and a pitch which will be invaluable for road-making. A Government refinery to deal with this crude petroleum is to be erected at Suez.

An inquiry into the possibility of cement manufacture in the Sudan was also undertaken. As a result a cement factory is now being constructed at Makwar, where 50,000 tons of cement per annum will be made; the fuel difficulty has been overcome by using a mixture of locally made charcoal and imported coke.

Among the chemico-legal cases dealt with was an interesting one in which a claim was made against the Government for land valued at about $16,000,000 l$. Unfortunatelv for the claimant, however, it was found that out of the I68 documents on which the claim was based no fewer than 163 were forged.

It is noted that an entirely new method of assaying gold has been devised, whereby the Assay Office was enabled to cope with a very considerable increase of work resulting from the new assay law, which provides for the compulsory hall-marking of gold and silver. The report indicates useful work and steady progress.

\section{The Problem of Soaring Flight. ${ }^{2}$}

THE source of energy used by birds in soaring flight is not yet clearly known. Attempts have been made to achieve this form of flight artificially, and, according to Gustav Lilienthal, a flight of 500 metres up wind, in which a height of 40 metres was attained, has been made by a man-carrying glider not provided with a motor, but having wings constructed on the pattern of those of a soaring bird.

The extraordinary regularity with which cranes, when flying in a group, keep their distances from one another affords a proof that such soaring flight is either due to undiscovered wing-movements or to some condition of the air which is widely and uniformly distributed. The observation that certain dragon-flies, and also flying-fishes, employ soaring

1 "Report on the Work of the Government Analytiral Laboratory and Assay Nffice, хоr3-roro." (Mini-try of F nance. F,gypt.)

Abstract of a paper bv Dr. F.. H. Hankin and F. Handley Page read before the Cimhrid re Philosophical Soc: ty on November 22.

No. 2668 , VOL. IO6] flight has led to discoveries that throw a new light on the subject. Dragon-flies can adjust their abdomens and hind-legs, and flying-fishes their pelvic fins, in such a way that these organs act as a brake to check speed when flying. The brake is used in certain conditions in continued flight to keep their speed at a required minimum. This use of an air-brake yields a proof that these instances of soaring flight are not due to undiscovered wingmovements. Dragon-files habitually avoid ascending currents when in soaring flight so long as the sun is shining. If isolated clouds are crossing the sky these insects collect in the neighbourhood of a convenient ascending current, entering it whenever the sun is obscured, and gliding beyond its range so soon as the sun comes out. That soaring flight is not due to the lifting effect of lateral gusts is proved by the fact that the fiying-fish when at highest speed carries its wings inclined so that the wing-tips are on a lower level than the bodv. In this case, if lateral gusts were operative, their only effect would be to drive the fish under water.

Certain facts suggest that turbulent motion is, in some unknown way, the source of the energy of soaring flight. But light objects, such as feathers or aerial seeds, mav be seen floating in the air in the neighbourhood of soaring birds, and exhibiting only slow and equable movement. What form of turbulent motion can be imagined that enables a bird weighing Io $1 \mathrm{~b}$, or more to glide without effort to a height of 2000 metres or to travel horizontally for indefinite distances at a speed of 50 miles an hour. and vet is unable to disturb the course of a piece of thistledown? Thus the facts of the case appear to offer insuperable difficulties to all theories that have hitherto been put forward as an explanation of soaring flight.

\section{University and Educational Intelligence.}

CAMBrIDGE.-The proposal to admit women to membership of the University on equal terms with men was rejected on December 8 by 904 votes to 7I2. The next step, presumably, will be a vote on Report B, the alternative proposal offered by the recent syndicate. This is, in effect, a suggestion on the part of the University that it would welcome the foundation of a separate University for women at Cambridge, and would extend to it the same facilities for educational purposes as are at present offered to the members of Girton and Newnham Colleges. This proposal dot's not in any way meet the greater number of the difficulties that were raised in connection with the rejected scheme, in particular the question of numbers and accommodation. It has already been rejected by the women's colleges, which have declared that they have no intention of taking action in the matter of forming a separate University even if Report B is passed. Already three of the six signatories of Report B have, in a sense, abandoned it for some scheme which shall more nearly meet the women's needs, a scheme the details of which have yet to be worked out. It does not look as though the adoption or rejection of Report B by the University will bring the problem nearer to an agreed settlement. In the interests of the University as a whole, and of the women's colleges in particular, an early settlement must be reached, and it looks as though the next move must lie with "the partv of thirteen," who have in view a scheme which will give the women the full privileges of membership of the University without anv control over the men's education. If thev take early and effective action they may be able to justify 